\title{
Do State-owned Enterprises in Brazil Require a Risk Premium Factor?
}

\author{
Rafaela Vitoria ${ }^{1}$ \\ rafaela.o.vitoria@gmail.com | (10 0000-0002-1656-8552 \\ Aureliano Angel Bressan ${ }^{1}$ \\ aureliano.bressan@gmail.com | (10) 0000-0002-9333-3394 \\ Robert Aldo Iquiapaza ${ }^{1}$ \\ riquiapaza@gmail.com | (1) 0000-0003-1657-2823
}

\begin{abstract}
Despite the extensive privatization achievements over the last decades, government ownership of publicly traded companies remains pervasive around the world. Consistent with past evidence of structural change in the beta coefficient during financial crises, the more recent economic recession of 2014 to 2016 in Brazil presents an opportunity to demonstrate the disadvantages of allocating investment in companies that are publicly traded, but are controlled by the government. Constructing a portfolio of publicly traded State Owned Enterprises, we find that the financial crisis produced a significant increase in risk exposure, results that were much more pronounced when compared with a portfolio of privatized companies. The results also indicate that, in addition to a market factor, the poor performance can be explained by controllership. We believe this study adds to the longstanding debate on whether state-owned firms perform worse than private firms, with higher volatility and lower returns, particularly, during a period of financial crisis.
\end{abstract}

\section{KEYWORDS}

State ownership, Privatization, Asset Pricing, CAPM, Financial Crisis

\author{
${ }^{1}$ Universidade Federal de Minas Gerais, \\ Belo Horizonte, MG, Brasil \\ Received: 06/11/2019. \\ Revised: $11 / 09 / 2019$. \\ Accepted: 01/20/2020. \\ Published Online: 07/13/2020. \\ DOI: http://dx.doi.org/10.15728/bbr.2020.17.5.1
}




\section{INTRODUCTION}

Despite the extensive privatization achievements over the last decades, government ownership of publicly traded companies remains pervasive around the world and, according to Boubakri et al. (2018), it accounts for nearly one-fifth of the world's stock market capitalization. The economic policy of privatization is an important element leading the increase in the use of markets to better allocate resources, reducing the influence of the government over business activity. The latest rise in state capitalism has emerged following the rapid economic growth of China and the bailouts needed as a result of the financial crisis of 2008. This has revived the debate about government ownership of publicly traded firms and the extent to which such involvement in the economy is beneficial (Megginson, 2017; Vining e Weimer, 2016; D’Souza \& Nash, 2017).

In Brazil, the combined market capitalization of state-owned companies represents close to $20 \%$ of the Brazilian equity market (B3), a relevant portion for any investor interested in asset allocation in the country. These state-owned enterprises are diversely distributed in key sectors, including commodities, utilities, and financial services. Analyzing the risk of an State-Owned Enterprise portfolio in Brazil is of particular importance for investors considering the strategic relevance to the stock market. Nonetheless, considering the past evidence of structural change in the beta coefficient in historical financial crises, the more recent economic recession of 2014 to 2016 presents an opportunity to further study such events. The aim of this study is then to evaluate the risk performance of Brazilian state-owned enterprises (SOEs), specifically during a market downturn and evaluate the need of an additional risk premium factor related to ownership.

According to Dinç and Gupta (2011), as controller of a firm, the government exercises interference to pursue other objectives rather than profit maximization. Our study shows this is more apparent during an economic crisis. Even partial privatizations, where state-owned companies are publicly listed with stock in the hands of minority private investors, can suffer from these distorted objectives, as only the transfer of management control to private shareholders can address the inefficiency in an SOE (Gupta, 2005). Lazzarini and Musachio (2018) studied state ownership in various forms of SOEs that are publicly listed and found that, particularly in economic downturns, state-controlled firms appear to be less responsive than private firms to negative shocks that require adjustments. Although stock markets can provide the right incentives towards value maximization, such as the need to disclose information and the constant monitoring by investors, the evidence of poor performance and higher stock price volatility corroborates the belief that the political interference exercised by the state control is exacerbated during an economic downturn (Borisova et al., 2015; Vining \& Weimer, 2016).

Investing in stocks implies risk, which can be measured by volatility of returns. In a recent study by Fama and French (2018), the average monthly risk premium of $0.51 \%$ in the US stock market had a volatility, measured by the standard deviation of $4.42 \%$, almost nine times larger, which creates substantial uncertainty about future realized premiums. Further, although the high volatility of stocks is common knowledge, Fama and French pointed out that many professional investors seem unaware of the implications of this. We discovered in our research of SOE stock returns that negative equity premiums can last almost 10 years. The negative premium combined with a higher than estimated beta can have a significant impact for investment management and asset allocation decisions.

As systematic risk relates to random market volatility, our study conducted empirical analysis of the possible existence of a changing relationship between the beta and the market risk premium during a complete economic cycle of boom and bust for a portfolio of state-controlled companies, 
BBR

17

490

and compared and contrasted this with a portfolio of privatized companies. Using a single factor as well as a multifactor model, we analyzed the performance of the portfolios from 2008 to 2016 . In light of the evidence of the impact of a financial crisis on the stability of betas, we examined the issue in terms of risk increase, particularly during the severe phase of a financial crisis that coincided with an economic recession. An adequate estimation of the risk factor has important implications for risk management and portfolio allocation. The impact of the economic crisis of 2014 to 2016 on the evolution of the beta is also relevant in helping us understand the lack of stability of the single-factor capital asset pricing model (CAPM) during a financial crisis.

We observed that during an economic crisis, such as the recession period of 2014 to 2016 in Brazil, the SOE stock price fluctuation increased, resulting in much higher risk than during a normal economic cycle. This increase in risk reflects that market agents expect governmentcontrolled companies to be less efficient and unable to reduce costs and adapt to an economic downturn compared with similar companies that are privately owned or have been privatized. We conclude that the financial crisis produced by an economic recession resulted in a structural change in the relationship between the SOE portfolio and the market, with a significant increase in risk exposure in addition to a negative market risk premium, results that were much more pronounced when compared with the privatized portfolio. The results also indicate that, in addition to a market factor, the poor performance can be explained by controllership. We believe this study contributes to the long-standing debate on whether state-owned firms perform worse than private firms, with higher volatility and lower returns, particularly during a period of financial crisis.

\section{LITERATURE REVIEW}

\subsection{SOE PERForMANCE}

There is an extensive body of literature on the inefficiencies of SOEs (e.g., Dewenter \& Malatesta, 1997; Shleifer \& Vishny, 1994; Meggison \& Netter, 2001; Gupta, 2005; Dinç \& Gupta, 2011 ; La Porta et al, 2002). However, despite significant privatization efforts over more than three decades, the last few years have brought a new wave of state capitalism. Lazzarini and Musachio (2018) investigated why, with so much evidence documenting the performance inferiority of state-controlled companies, there are still a large number of SOEs as well as resistance to privatization. Among the top 100 firms ranked by Fortune 500 in 2013, 25 were SOEs.

Considering the resilience of the SOEs, Lazarini and Musachio studied the performance of 477 large SOEs in 66 countries between 1997 and 2012, and with matching techniques selected 431 privately controlled companies for a comparison. The authors concluded that regarding state capitalism, the key question was not whether SOEs underperformed private companies, but when and where. They found that SOEs underperformed their private peers during times of economic downturns, as they tended to be less efficient at cutting costs and adjusting to shocks. In addition, they concluded that the government's negative influence on SOEs was higher in countries with weaker local institutions wich are unable to constrain political interference. Thus, the differences were not static but varied depending on the likelihood of government intervention and the temptations to intervene. The Brazilian recession of 2014-16 thus presents an opportunity to particularly test the SOE performance and the the results of local government intervention. 


\subsection{CAPM, Fama-French Model, and Empirical Evidence in Brazil}

The CAPM built on Markowitz's (1959) mean-variance portfolio model and developed by Sharpe (1964), Lintner (1965), and Black (1972), remains the basis of modern financial economics despite the many important empirical challenges to the model's strength over the years. It is widely used in academic research and practical security analysis and portfolio management, even as criticism has continued. The CAPM is a model that links the market risk that all companies are subjected to and the expected return of a given security or portfolio.

Based on the CAPM methodology, Black (1972) derived the market model, with the purpose to develop an alternative, more economical method to conduct conditional beta tests. While the Sharpe (1964), Lintner (1965), and Black (1972) model is stated in terms of expectations, the empirical applications entail the use of historical data. Specifically, we base ex ante expectations on ex post observations. The market model embodies the same conditional relation among the variables: realized beta of market excess returns and realized excess portfolio return. The market model can be stated as:

$$
\mathrm{r}_{\mathrm{pt}}=\alpha_{\mathrm{p}}+\beta_{\mathrm{p}}\left(\mathrm{r}_{\mathrm{mt}}-\mathrm{r}_{\mathrm{f}}\right)+\varepsilon_{\mathrm{pt}}
$$

where

$r_{p t}=$ the excess-return on portfolio $p$

$r_{m t}=$ the excess-return on the market portfolio

$\mathrm{r}_{\mathrm{f}}=$ the risk-free rate

$\beta_{\mathrm{p}}=$ the portfolio's beta

$\alpha_{\mathrm{p}}=\mathrm{a}$ fixed term for a given portfolio $\mathrm{p}$

$\varepsilon_{\mathrm{pt}}=$ error term

The CAPM has received a lot of criticism through the years. Some refer to the lack of efficiency and comprehensiveness of the beta and suggest the need for additional explanations. For instance, Chen, Roll and Ross (1986) argued in favor of measuring systematic responsiveness to macroeconomic variables. Other researchers, such as Lakonishok and Shapiro (1986), found empirical evidence that security returns were affected by measures of unsystematic risk.

Fama and French (1992) asserted that empirical evidence indicates the absence of a systematic relationship between the beta and security returns implying that beta does not fully measure risk. The three-factor model, or the Fama French model, expands on the CAPM by adding size risk and value risk factors to the market risk factor. The inclusion of two additional factors is believed to make the model a more robust tool for evaluating a portfolio performance.

Other researchers have confirmed the usefulness of the CAPM in many instances. Through empirical tests, Pettengill et al. (1995) found support for the market model using average realized returns as a proxy for expected returns and an index of equity security returns as a proxy for the market. However, the implicit assumption that expected excess market-returns should be positive was questioned when, in fact, realized excess market returns are negative, especially during a crisis or a recession. When realized market returns fall below the risk-free rate, an inverse relationship is predicted between realized returns and beta. Pettengill et al. (1995) suggested a model that allowed tests of beta that are conditioned on excess market return by separately investigating the 
BBR

17

492

effect of beta on portfolio returns when realized excess market returns are negative and when realized excess market returns are positive. Beta may change as the return interval changes, as we will observe in the results of this study.

Bollerslev, Engle, and Wooldridge (1988) analyzed the autoregressive model of conditional duration and observed variation in the estimates for beta for various sub-periods, concluding that beta may vary over time. Slimane, Bellalah, and Rjiba (2017) studied the impact of the global financial crisis of 2008 with their results indicating that a rise in beta due to high volatility returns, in some cases, had a direct impact on beta systematic risk. This increase in beta could be an important component in investors' portfolio decisions.

Despite the evidence in favor or against the market model, academics and market professionals still think about risk in terms of market price volatility. We assume that the preference for beta comes from the convenience of using a single factor to measure risk and its intuitive appeal. Thus, the use of beta may be justified as a measure of risk, even if beta in certain instances may be less efficient than alternative measures of systematic risk or is an incomplete measure of risk.

The literature on the CAPM for the Brazilian stock market (B3) is mixed with previous studies including validation and improvements in the application of the asset-pricing model. Sanvicente (2017) tested the use of a local CAPM, analyzing Brazilian market data, including stock returns and the risk-free rate and concluded that the model was also valid in Brazil, even without the use of an additional country risk premium due to the integration with global markets. The performance of the Brazilian market portfolio already incorporated the country risk.

Rogers and Securato (2009) studied the single-factor CAPM in addition to the three-factor model from Fama and French in the Brazilian market from 1996 to 2000. They concluded that the multifactor model was superior, but not including the specific high minus low (HML) value factor.

In a study by Noda, Martelanc, and Kayo (2015), the risk factor price-to-earnings ratio was also included in the traditional CAPM. The results from the study from 1995 to 2014 indicated that the price-to-earnings ratio was a complementary factor to the CAPM beta effect after controlling other components of the Fama and French model.

Silva, Pinto and Melo (2012) compared the traditional CAPM and the conditional form with the purpose of analyzing its predictive power and the presence of structural change over time for stock portfolios represented by Bovespa sectorial indices. They concluded that although the coefficient beta was statistically significant in the regressions, they found significant differences in the systematic risk in the sub-periods.

In a more recent study, Bortoluzzo et al. (2016) analyzed the single-factor CAPM and the threefactor Fama and French model during the 2008 crisis. The results from time series regressions with Brazilian stock portfolios indicated that the market risk factor was the most important for explaining portfolio returns, but not the only statistically significant factor. They also found differences in the risk premium by breaking the analyzed period into sub periods, including the 2008 financial crisis. The study indicated that there was a structural change in the time series. 


\subsection{PorTfolio RISK DURING FINANCIAL CRISIS}

Lo (2012) analyzed the behavior of investors during a financial crisis to address some of the criticism resulting from the use of traditional models that rely on assumptions such as the positive tradeoff between risk and reward across all financial investments; namely, that assets with higher risk offer higher expected returns and that this trade-off is linear as risk is best measured by equity "beta" and excess returns by "alpha," the average deviation of a portfolio's return from the CAPM benchmark. Lo (2012) pointed out that not only was that relationship not linear, but that asset returns were not stationary, and investors also behaved irrationally. Although he argued in favor of an adaptive market hypothesis, as investors learned from past crises, particularly dues to largescale economic changes, financial market dynamics can change.

Page and Panariello (2018) also documented asset pricing during a financial crisis, showing that the reduction of risk through portfolio diversification tended to fail during a period of crisis, as the correlation changed in times of acute risk aversion. Financial markets tended to fluctuate between a low-volatility state and a panic-driven, high-volatility one. In addition, investor sentiment was a major factor as during a crisis, as opposed to a normal market, investors often sold riskier assets irrespective of differences in fundamentals.

Marsh and Pfleiderer (2013) studied market dislocation during a financial crisis and concluded that when investors suffer losses and diversification can no longer reduce risk, the natural inclination is a flight to quality. This can produce increased volatility in riskier assets.

Lins, Servaes and Tamayo (2017) studied the behavior of stocks during the global financial crisis of 2008 and the differences in performance and volatility. Considering the measure of corporate social responsibility (CSR), they found that firms with higher CSR significantly outperformed firms with lower CSR. This conclusion was a reflection of the social capital built up, in this case based on CSR activities, which proved to be relevant when the importance of trust increased unexpectedly such as during the 2008 financial crisis. In Lins et al.'s conclusion, the enhanced performance of the higher CSR companies correlated with higher profitability, sales growth, and employee productivity relative to lower CSR companies, as well to the characteristics of stateowned entities as a result of their political interference.

Beuselinck (2017) studied the relation between government ownership and the value of European firms during the global financial crisis of 2008 and found that SOEs were less volatile during the crisis as state controllership was perceived as positive in weathering the storm. However, this was true only in countries with strong investor protection and high-level governance institutions rather than in developing countries with higher rates of corruption. The study concluded that the government can help stabilize a firm's cost of debt with implicit and explicit government guarantees to alleviate financial supply shocks.

Boubakri et al. (2018) analyzed listed SOEs to answer the question of whether governments influence the valuations of publicly traded firms. Specifically, they investigated whether the relationship between government ownership and corporate valuation was influenced by the quality of the institutions and the government in place. Examining a large sample of companies in Asia from 2006 to 2010, they argued that market valuation was relevant because it represented investor expectations of future cash flows, a different view from accounting standards for efficiency. The result was that government controlling rights in excess of $50 \%$ translated into lower valuations. 


\section{METHODOLOGY}

In this study, we used the CAPM and Fama-French models to analyze the return on a portfolio of all government-controlled companies listed in the Brazilian stock market and compared the results with the performance of a portfolio of companies previously privatized. Since its inception in the 1960s, the CAPM has been a dominating capital market equilibrium model, and it is still widely used in academic research and practical portfolio management. However, our study shows that the portfolio beta is an incomplete measure of risk, particularly during a financial crisis. The choice of the CAPM (Sharpe, 1964; Lintner, 1965) is often due to its simplicity and relevance for the analysis of non-systematic risk in stock portfolios. As the single-factor model has been criticized often, we also tested the results using the three-factor Fama-French model. Although the SOE risk could be partially explained by the market beta, it was not stable enough to explain the investment return during the period including the financial crisis. We conclude that there is clear evidence of the appropriateness of the use of the CAPM model to analyze risk in the Brazilian market, given its simplicity and empirical results over time. We acknowledge the existing critics, particularly those who advocate for the inclusion of additional factors to enhance the model, which we will discuss in our conclusion.

\subsection{The SOE Portfolio}

Currently, there are a total of 23 companies listed on the Brazilian stock exchange B3 that are controlled by the government in Brazil. The definition of control for any listed corporation, financial and non-financial, is determined by voting shares of $50 \%$ or more owned by the government, either at the federal or state level. We collected monthly stock prices for the 23 companies for the period 2008 to 2016 from Bloomberg. All 23 companies were included in our SOE portfolio using the market weight of each stock, with a maximum allocation of $20 \%$ for any individual stock, following the rules used by B3 for sector portfolio indices. Governmentcontrolled companies that went public and listed their stocks during the analyzed period were also included in the portfolio in the month of their initial public offering (IPO) in the proportion of their market weight. The list of all companies is in Appendix A.

The portfolio was rebalanced every quarter, and we matched the rebalance procedure of the B3 indices. The period chosen, from 2008 to 2016, represents one economic cycle, beginning with the recovery period after the 2008 crisis through the end of the last crisis in 2016.

\subsection{The Privatized Portfolio}

Among all companies listed in the Brazilian stock market, B3, there are 22 that were previously government controlled and were privatized. A privatized company is defined as a company or a service concession that was once state owned and then auctioned to private shareholders. Most relevant privatizations in Brazil occurred in the 1990s including steel and mining companies, telecommunication, electric generation, transmission and distribution companies. We also included firms that were formed after acquiring new concessions to manage toll roads and railways, and in the electricity and telecom sectors that were auctioned during the 2000s. The same procedures for the SOE portfolio were replicated for the privatized one.

Although we understand that a matching technique for selecting the privately-owned portfolio for comparison purposes is preferred, the size of the Brazilian market presents a constraint for such an approach. However, it is worth noting that our privatized portfolio had a similar sector allocation as the SOE portfolio, including utilities, commodities, and financial services. A list of all privatized companies is included in Appendix B. 


\subsection{Market Portfolio and Risk Free Rate and Risk Factors}

As a proxy for the market portfolio, we used the IBX index, which represents the 100 largest

companies by market cap listed on B3. Although IBOVESPA is a more popular market index in Brazil, it went through methodology changes during the period under analysis, while the IBX did not. After the changes, the two indices have become very similar, and the observed correlation in the last 36 months is over $99 \%$.

The risk-free rate we used was the monthly CDI, the Brazilian interbank deposit rate, and the most common benchmark in Brazil for security returns. All rates used were nominal in local currency. For the multifactor model, we used Nefin's database (http://www.nefin.com.br) for the factors small minus big (SMB) and high minus low (HML).

The models were estimated using ordinary least squares (OLS). The robustness of the model was tested using $\mathrm{t}$ statistics and Shapiro tests. The comparison of the means and variances were also tested using t statistics, the F test, and the Kruskal and Wallis test. We tested the regression for structural changes with the Chow test.

\subsection{The Sub-Period of Analysis}

We were most interested in analyzing the crisis of 2014 to 2016, which represented the most severe economic recession in Brazil since 1930. The crisis period was defined by the maximum drawdown in the stock market, which occurred between September 2014 and February 2016. We included in the analysis the pre-crisis period of 2008 to 2014 , forming a database of an entire economic cycle, comprising a recovery period, a boom, and a bust. The following period between 2016 and 2018 represented the start of a new recovery phase marked by a change in government and economic policy, marked by news of a fresh privatization program.

\section{RESULTS}

The first stage of our empirical analysis included the Brazilian market risk premium assessment over the eight-year period between 2008 and 2016 and the sub-periods, the pre-crisis and the crisis. The risk premium was positive before the crisis, although without statistical relevance as shown in Table 1 . However, during the crisis, the excess market return was negative by a significant margin, with an average of $-3 \%$ per month, comparable results with previous crisis, such as 2008-09 (Grouta \& Zalewska, 2016).

Observing the total period, we noticed that the monthly average risk premium was negative at an average of $0.3 \%$ per month, but not significantly different from 0 . This estimated value was lower than the values found by Sanvicente (2017), Bortoluzzo (2016), and Mussa, Roger and Securato (2009), which were between $1 \%$ and $2 \%$ in their previous studies in Brazil. We attribute the difference to the severity of the financial crisis in 2014 to 2016 that was a result of the worst economic recession in the country since 1930. We tested the difference between the risk premium calculated during the crisis and in the pre-crisis periods and found that the means were significantly different, both through a two-sample t test and a Wilcoxon test, as the smaller sample normal distribution assumption was rejected. Figure 1 illustrates the estimates and the distribution. We noted a small increase in the variance of the risk premium during the crisis; however, through the $\mathrm{F}$ test, we rejected any significant differences in the variances. It is noteworthy that the standard deviation of 5.5 and a range of 26.4 for monthly returns were rather high, illustrating the extraordinary volatility of the Brazilian equity risk premium in the period. 
BBR

17

496

Table 1

Brazilian Risk Premium Analysis

\begin{tabular}{lccc}
\hline & Total period & Pre-Crisis & Crisis \\
\cline { 2 - 4 } & $2008-2016$ & $2008-2014$ & $2014-2016$ \\
\hline Risk Premium Monthly Average & -0.3 & 0.4 & -3.1 \\
SD & 5.2 & 4.9 & 5.6 \\
Min & -12.2 & -9.7 & -12.2 \\
Max & 12.3 & 12.3 & 8.5 \\
Range & 24.5 & 22.0 & 20.7 \\
$\mathrm{t}$ & -0.5 & 0.6 & -2.3 \\
p-value & 0.6 & 0.6 & $<.001$ \\
\hline
\end{tabular}

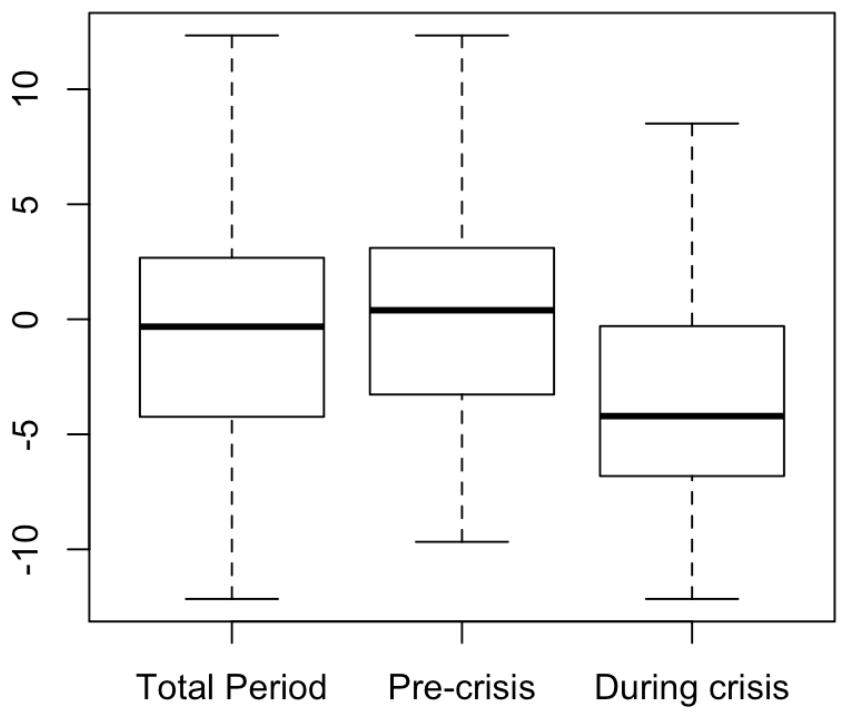

Figure 1. 2008-2016 Brazilian Market Risk Premium: Monthly Mean and Volatility.

In the second stage of this study, we constructed the SOE portfolio and compared its performance with the market portfolio, as measured by the IBX index, and the risk-free rate. Considering the entire period, the SOE portfolio underperformed the market portfolio by an average of $0.7 \%$ annually. The severity of the crisis negatively impacted the stock market but ,more so, the state-owned entities, which underperformed as a result of less efficiency in adapting to the new scenario, which required costs and investment reductions, and workforce layoffs. The SOE portfolio also underperformed the privatized portfolio, even though both portfolios contained similar sector allocation. The variance in the privatized portfolio was also much lower compared with the market portfolio, reflecting management's ability to cope with the economic crisis.

In a study of performance differences between state-owned and private firms, Lazzarini and Musacchio (2018) found that the major difference in their returns, measured mainly by return on assets (ROA), occured in negative environments. The results indicated that political intervention caused the SOEs to deviate from their more normal course of action, as governments were more tempted to interfere to boost the economy using every means, including directing the companies against profit maximization. 
Table 2 summarizes the performance comparison of the two portfolios, while Figure 2 illustrates the difference in the monthly results and the volatility. The high volatility in both the market portfolio and the SOE portfolio shows no compensation in the form of excess returns during the period.

Table 2

Portfolio Return Analysis

\begin{tabular}{lcccc}
\hline & Total Return & Annualized Return & SD Monthly Return & $\begin{array}{c}\text { Monthly Range } \\
\text { (Max-Min) }\end{array}$ \\
\hline $\begin{array}{l}\text { Market Portfolio } \\
\text { (IBX) }\end{array}$ & $45 \%$ & $5.2 \%$ & 5.2 & 24.4 \\
SOE Portfolio & $38 \%$ & $4.5 \%$ & 6.8 & 34.4 \\
Privatized Portfolio & $48 \%$ & $5.5 \%$ & 4.7 & 20.3 \\
Risk Free Rate & $107 \%$ & $10.4 \%$ & 0.2 & 0.7 \\
\hline
\end{tabular}

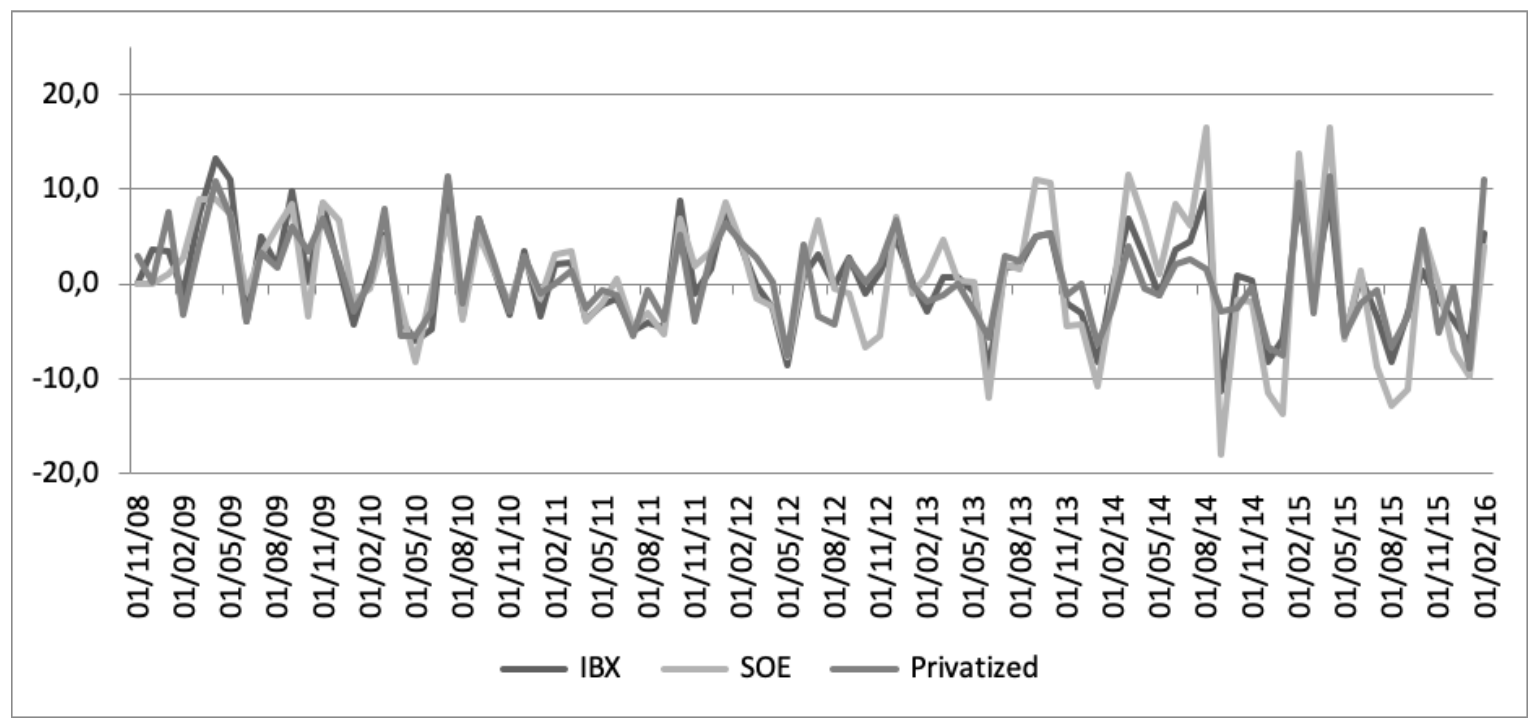

Figure 2. Portfolios' Monthly Returns. 
BBR

17

498

In the third stage, we calculated the excess return on the SOE portfolio and ran OLS regressions on the market excess return to estimate the portfolio beta during the 2009 to 2016 period. Three models were estimated, pre-crisis, crisis, and for the total period, with the crisis period determined as described in the methodology. The results are shown in Table 3.

Table 3

Summary Statistics of OLS Regression of SOE Portfolio on the Market Portfolio

\begin{tabular}{lccc}
\hline & Total period & Pre-Crisis & During Crisis \\
\cline { 2 - 4 } & $2009-2018$ & $2009-2014$ & $2014-2016$ \\
\hline$\alpha$ & 0.1 & 0.5 & 0.2 \\
$\mathrm{t}$ & 0.3 & 1.5 & 0.2 \\
$\mathrm{p}$-value & 0.82 & 0.14 & 0.85 \\
$\beta$ & $\mathbf{1 . 1 6}$ & $\mathbf{0 . 9 8}$ & $\mathbf{1 . 6 2}$ \\
$\mathrm{t}$ & 17.7 & 14.0 & 12.8 \\
$\mathrm{p}$-value & $<0.01$ & $<0.01$ & $<0.01$ \\
$\mathrm{R}^{2}$ & 0.78 & 0.74 & 0.91 \\
$\mathrm{~N}$ & 88 & 70 & 18 \\
\hline
\end{tabular}

As expected, our research showed that the SOE portfolio presented a beta of 1.16 during the total period. As previous studies have shown, state-owned companies are less profitable, less efficient, with higher leverage, and less investment than before privatization (Megginson, Nash, \& Randenborgh, 1994). A high beta can express the higher risk of a portfolio of less profitable, highly leveraged companies that are more susceptible to cyclical exposure. As Lima and Sanvicente (2013) demonstrated, investors recognize higher risk in low governance and less efficient companies and, therefore, require higher returns on these investments, which can be reflected in higher beta.

However, after breaking the analysis into distinct periods, we observed that a high beta was not present during the entire period. By examining the sub-periods, as shown in Table 3, we noticed that the pre-crisis beta was closer to 1 versus a beta of 1.6 during the crisis period. It appears that during an economic upturn, state-controlled companies are able to present adequate growth and the market perception of risk does not differ from the market portfolio. In addition, the recent study by Boubakri et al. (2018) using a sample of Asian companies found that state-owned firms may enjoy a higher market valuation relative to non-government-owned firms when ownership is less than $50 \%$. The reasons for this positive valuation by the market include financing decisions and the discount rate applied by investors. Further, a period of sound economic growth could mask the ownership risks and induce investors to over value SOEs.

In the presence of a negative market premium, Pettengill (1995) showed that, as expected, high beta portfolios incur lower returns during down markets than low beta portfolios, providing further corroborative evidence of the expected association between beta and portfolio returns. However, the SOE portfolio behavior changed over time with a time-varying beta in addition to a significant change in market risk. Investors may have chosen to allocate resources in a portfolio of companies with an average beta close to 1 for a market risk premium of $0.4 \%$, as in the precrisis period, with the actual result in the following period a much higher risk premium of 1.6 with a negative premium of $3 \%$. 
Marsh and Pfleiderer (2013) also exposed the increase in the volatility in asset returns as asset prices dropped sharply during the 2008 financial crisis as market factors increased in relative importance. It appears that the natural response to a crisis, at least for many investors, is to "flee to safety," as confidence in the market erodes and prospects dim. The significant increase in state-owned company volatility during 2014 to 2016 appears to reflect the view of the SOE as a riskier asset that needs to be sold during a time of higher uncertainty, which is not captured by beta during the normal market, as in the pre-crisis period.

The observed structural change in the sub-period regression was also tested with the Chow test, confirming the existence of differences in the model before the crisis and after during the recovery period. With a $5 \%$ level of significance, we rejected the null hypothesis that the coefficient was stable.

The parallel analysis of a privatized portfolio also confirmed our conclusions. As shown in Table 4, the privatized portfolio had a lower risk, represented by its beta of less than 1 . Although the risk increased during the crisis as well, the increase was less pronounced, and beta was still below 1 .

Table 4

Summary Statistics of OLS Regression of Privatized Portfolio on the Market Portfolio

\begin{tabular}{lccc}
\hline & Total period & Pre-Crisis & During Crisis \\
\cline { 2 - 4 } & $2009-2018$ & $2009-2014$ & $2014-2016$ \\
\hline$\alpha$ & -0.1 & -0.2 & 0.1 \\
$\mathrm{t}$ & -0.2 & -0.9 & 0.2 \\
$\mathrm{p}$-value & 0.84 & 0.44 & 0.86 \\
$\beta$ & $\mathbf{0 . 7 9}$ & $\mathbf{0 . 7 2}$ & $\mathbf{0 . 9 1}$ \\
$\mathrm{t}$ & 15.5 & 13.9 & 6.9 \\
$\mathrm{p}$-value & $<0.01$ & $<0.01$ & $<0.01$ \\
$\mathrm{R}^{2}$ & 0.73 & 0.73 & 0.74 \\
$\mathrm{~N}$ & 88 & 70 & 18 \\
\hline
\end{tabular}

Last, we tested the three-factor model for the SOE portfolio and found that the added variables did not help explain portfolio performance having statistics that were not significant at the 5\% level. Results are shown in Table 5.

Table 5

Summary Statistics of OLS Regression of SOE on the three-factor model

\begin{tabular}{lcccc}
\hline & $\alpha$ & Market factor & HML factor & SMB factor \\
\hline Coefficient & $\mathbf{0 . 1 5}$ & $\mathbf{1 . 1 6}$ & $\mathbf{0 . 1 2}$ & $\mathbf{- 0 . 0 6}$ \\
$\mathrm{t}$ & 0.4 & 16.9 & 1.2 & -0.9 \\
$\mathrm{p}$-value & 0.7 & $<.001$ & 0.2 & 0.4 \\
$\mathrm{R}^{2}$ & 0.78 & & & \\
$\mathrm{~N}$ & 88 & & & \\
\hline
\end{tabular}

R-squared was high for all models, but highest for the single-factor model during the crisis sub-period, accounting for more than $91 \%$, indicating that the market risk premium could be the most important single factor explaining SOE performance during the period of financial distress. The lower beta and somewhat lower $\mathrm{R}$ squared in the pre-crisis period indicated that 
other factors may explain the result of the SOE portfolio in this period. Our research suggests an ownership factor should be studied further to add to the market risk factor and help value SOEs in any stage of an economic cycle.

\section{CONCLUSION}

Our study analyzed exposure to market risk using the single-factor asset-pricing model for a Brazilian portfolio of SOEs in the period 2009 to 2016. Time series regressions were analyzed for the entire period and sub-periods, emphasizing the 2014 to 2016 economic recession. The empirical findings suggest that the SOE portfolio does not show a stable beta over time. In fact, despite a beta close to 1 during the expansion of the economic cycle, during the market turbulence caused by the recession, the portfolio risk increased by almost $70 \%$, which resulted in significant negative returns below the market portfolio. The study found that the structural change in the CAPM and the increased risk during a period of crisis could be attributable to investor expectations that state-owned companies would be unable to adapt as quickly as their private counterparts during an economic downturn, as investors' confidence significantly diminished during this timeframe. The Fama-French three-factor model did not help explain the differences in performance. As other studies on privatizations have shown (Dewenter \& Malatesta, 2001), that state-owned companies are significantly less profitable as a result of lower efficiencies, usually from more employees, considering their political use, differences which can increase during a recession period. By contrast, Lins, Servaes and Tamayo (2017) showed that, during times of crisis, well-managed and highly efficient companies with stronger corporate governance and greater social responsibility can retain investor trust and weather the crisis with lower volatility, as demonstrated in the privatized portfolio.

Performance differences between private companies and SOEs were larger during the crisis. The implication is that private companies are more flexible and can adjust and cut costs, such as through layoffs, while SOEs are pressured to retain employees and investments at all times. This happens when SOEs are controlled by the state and not when the state is only a minority shareholder. When the state is constrained, SOEs are managed like private firms.

Our analysis offers important implications for investors and portfolio managers, whose main objective is to develop efficient portfolios with greater expected return for a given class of quantifiable beta risk. In this sense, the results implicate that SOE are riskier than privately owned enterprises during moments of high volatility, which is not expressed in the CAPM beta during the pre-crisis period, with privatized portfolios presenting lower risk in both scenarios.

The empirical results also indicate a further research agenda, related to the fact that there may be other factors influencing the performance of the SOE portfolio that we did not capture in the CAPM or in the Fama-French model. In this sense, it can be investigated if a fraction of the risk not explained in these models may have arisen from the fact that the SOEs' managers were not well equipped to handle financial crises. Further analysis could test for other factors such as a specific ownership factor that influences the performance of a state-owned company during a financial crisis compared with a privately owned one, may be a path for future research on this topic. 


\section{REFERENCES}

Beuselinck, C., Cao, L., Deloof, M., \& Xia, X. (2017). The value of government ownership during the global financial crisis. Journal of Corporate Finance, 42, 481-493.

Black, F., Jensen, M., Scholes, M. 1972. “The capital asset pricing model: Some empirical tests.” In: M.C. JENSEN (org.), Studies in the theory of capital markets. New York, Praeger, p. $79-121$.

Bollerslev, T., Engle, R. F., \& Wooldridge, J. M. 1988. "A capital asset pricing model with timevarying covariances." Journal of Political Economy, 96(1), 116-131.

Borisova, G., Fotak, V., Holland, K., Megginson W. 2015. "Government ownership and the cost of debt: evidence from government investments in publicly traded firms." Journal of Financial. Economics, 118(1), 168-191

Bortoluzzo, A. B., Venezuela, M. K., Bortuluzzo, M. M., Nakamura, W. T. 2016. "The influence of the 2008 financial crisis on the predictiveness of risky asset pricing models in Brazil." Revista de Contabilidade e Finanças USP, 27(72), 408-420

Boubakri, N., Ghoul, S., Guedhami, O., Megginson, W. 2018. "The market value of government ownership." Journal of Corporate Finance, 50, 44-64

Boubakri, N.; Cosset, J.-C.; and Saffar, W. 2017 “The Constraints on Full Privatization: International Evidence." Journal of Corporate Finance, 42, 392-407.

Chen, N., Roll, R. and Ross, S.A. 1986. Economic Forces and the Stock Market. Journal of Business, 59, 383-403.

D'Souza, J., \& Nash, R. 2017. Private benefits of public control: Evidence of political and economic benefits of state ownership. Journal of Corporate Finance, 46, 232-247.

Dewenter, K., Malatesta, P. 2001. "State-owned and privately owned firms: An empirical analysis of profitability, leverage, and labor intensity." American Economic Review, 91(1) 320-334.

Dinç, I. S. and N. Gupta. 2011. The decision to privatize: finance and politics. Journal of Finance. 66, 241-269.

Fama, E. F., French K. R. 2018. 'Volatility Lessons.” Financial Analyst Journal 47, 427- 465.

Fama, E. F., French K. R. 1992. "The cross-section of expected stock returns." Journal of Finance $74,42-53$.

Grouta, P. A., Zalewska, A. 2016. "Stock market risk in the financial crisis." International Review of Financial Analysis 46, 326-345.

Gupta, N. 2005. Partial Privatization and Firm Performance.” Journal of Finance, 60(20), 987-1015.

La Porta, R., Silanes, F., Shleifer, A. 2002. “Government ownership of banks.” The Journal of Finance, 57 (1) 265-301.

Lazzarini, S.G., Musacchio A. 2018. State ownership reinvented? Explaining performance differences between state-owned and private firms. Corporate Governance An International Review, 26, 255-272.

Lima, B., and Sanvincente, A. 2013. "Quality of Corporate Governance and Cost of Equity in Brazil. "Journal of Applied Corporate Finance 25 (1) 72-81.

Lintner, J. 1965. "The valuation of risk assets and the selection of risky investments in stock portfolios and capital budgets." Review of Economics and Statistics 47(1), 13-37. 
BBR

17

502
Lins, K. V., Servaes, H. and Tamayo, A. 2017. "Social Capital, Trust, and Firm Performance: The Value of Corporate Social Responsibility during the Financial Crisis." The Journal of Finance, 72, (4).

Lo, A. W. 2012. "Adaptive Markets and the New World Order." Financial Analysts Journal 68 (2). 18-29.

Markowitz, H. 1959. Portfolio Selection: Efficient Diversification of Investments. New York: Wiley.

Marsh, T., Pfleiderer, P. 2013. "Flight to Quality and Asset Allocation in a Financial Crisis." Financial Analysts Journal 69 (4), 43-57.

Megginson, W. L., Nash M. 1994. "The Financial and Operating Performance of Newly Privatized Firms: An International Empirical Analysis.” Journal of Finance 49 (2), 403-452.

Megginson, W.L., Netter J.M. 2001. "From state to market: a survey of empirical studies on privatization." Journal of Economic Literature 39 (2), 321-389

Megginson, W. L. 2017. "Privatization, state capitalism, and state ownership of business in the 21st century." Foundations and Trends in Finance, 11(1-2), 1-153

Mussa, A., Rogers, P., \& Securato, J. R. 2009. "Modelos de retornos esperados no mercado brasileiro: testes empíricos utilizando metodologia preditiva." Revista de Ciências da Administração, 11 (23), 192-216.

Noda, R. F., Martelanc, R., \& Kayo, E. K. 2015. “The earnings/price risk factor in capital asset pricing models." Revista Contabilidade \& Finanças, 27 (70), 67-79.

Page, S., Panariello, R. O. 2018. “When Diversification Fails.” Financial Analysts Journal 74 (3), 19-32.

Pettengill, G. N., Sundaram, S., Mathur, I.. 1995. "The conditional relation between beta and returns." Journal of Financial and Quantitative Analysis 30, 101-116.

Rogers, P., and Securato, J. R. 2009. Estudo comparativo no mercado brasileiro do capital asset pricing model (CAPM). RAC Eletrônica, 3(1), 159-179.

Roll, R. 1977. "A critique of the asset pricing theory's tests. Part 1. On past and potential testability of the theory." Journal of Financial Economics, 4, 129-176.

Sanvicente, A. Z., Sheng, H., Guannais L. F. 2017. "Are Country and Size Risks Priced in the Brazilian Stock Market?” Brazilian Administration Review. 14 (1), e160076.

Silva, W. A. C., Pinto, E. A., Melo, A.A. 2012. "The CAPM and conditional CAPM in pricing stock indexes: evidence of changes in the estimated coefficients from 2005 to 2008." Revista de Administração Mackenzie, 13(2), 106-134.

Slimane, I. B., M. Bellalah and H. Rjiba. 2017. "Time-varying beta during the 2008 financial crisis evidence from North America and Western Europe.” The Journal of Risk Finance, 18(4), 398-431.

Sharpe, W. F. 1964. "Capital asset prices: A theory of market equilibrium under conditions of risk." Journal of Finance 19 (3), 425-442.

Shleifer, A., Vishny, R. W. 1994. Politicians and firms. Quarterly Journal of Economics, 109, 9951025.

Vining, A. R., \& Weimer, D. L. (2016). The challenges of fractionalized property rights in public-private hybrid organizations: The good, the bad, and the ugly. Regulation \& Governance, 10, 161-178. 
All authors contributed to the elaboration of the study. The leading author conceived and designed the analysis, collected the methodology that was applied, analyzed and discussed the results.

\section{CONFLICTS OF INTEREST}

There are no conflicts of interest in the present article or during its elaboration. 
BBR

17

504
APPENDIX A

SOE Portfolio description by ticker and company name

\begin{tabular}{ll}
\hline Stock Ticker & \multicolumn{1}{c}{ Company Name } \\
\hline PETR4 & Petróleo Brasileiro -Petrobrás \\
BBAS3 & Banco do Brasil \\
BBSE3 & BB Seguridade Participaçôes \\
ELET6 & Centrais Elétricas Brasileiras - Eletrobrás \\
SBSP3 & Cia de Saneamento Básico do Estado de São Paulo \\
CMIG4 & Cia Energética de Minas Gerais - Cemig \\
BRSR6 & Banco do Estado do Rio Grande do Sul \\
CASN4 & Cia Catarinense de Agua e Saneamento \\
CPLE6 & Cia Paranaense de Energia - Copel \\
CSMG3 & Cia de Saneamento de Minas Gerais \\
CESP6 & Cia Energética de Sáo Paulo \\
SAPR4 & Cia de Saneamento do Paraná \\
LIGT3 & Light \\
BNBR3 & Banco do Nordeste \\
CLSC4 & Centrais Elétricas de Santa Catarina \\
BEES4 & Banco do Estado do Espirito Santo - Banestes \\
BSLI4 & Banco de Brasília \\
BAZA3 & Banco da Amazônia \\
EMAE4 & Empresa Metropolitana de Aguas e Energia \\
BGIP4 & Banco do Estado de Sergipe \\
CEBR6 & Cia Energética de Braśilia \\
CEED4 & Cia Estadual de Distribuiçáo de Energia \\
GPAR3 & Cia Celg de Participaçóes \\
\hline
\end{tabular}


Privatized Portfolio description by ticker and company name

Stock Ticker Company Name

SANB11

Banco Santander Brasil

VALE3

Vale

VIVT4

Telefônica Brasil

BRKM5

Braskem

TIMP3

Tim Participaçôes

EGIE3

Engie Brasil Energia

UGPA3

Ultrapar Participaçôes

$\mathrm{CCRO} 3$

CCR

EMBR3

Embraer

CSNA3

Cia Siderúrgica Nacional

ENGI11

Energisa

USIM5

Usinas Siderúrgicas de Minas Gerais

EQTL3

Equatorial Energia AS

TRPL4

Cia de Transmissão de Energia Elétrica Paulista

ENBR3

Energias do Brasil

TAEE11

Transmissora Aliança de Energia Elétrica

CGAS5

Cia de Gás de São Paulo

ELPL3

Eletropaulo Metropolitana Eletricidade de São Paulo

OIBR 4

$\mathrm{Oi}$

ECOR3

Ecorodovias Infraestrutura e Logística

TIET11

Aes Tiete Energia

STBP11

Santos Brasil Participação 